\title{
A “LATTICE" APPROACH TO DESIGN EDUCATION: BRINGING REAL AND INTEGRATED DESIGN EXPERIENCE TO THE CLASSROOM THROUGH ENGINEERING DESIGN DAYS
}

\author{
Hurst, Ada; Rennick, Chris; Bedi, Sanjeev \\ University of Waterloo
}

\begin{abstract}
While design is fundamental to engineering practice, modern training in engineering design has almost exclusively moved to the classroom, providing students little exposure to holistic, real-world design experiences that are well-integrated with the rest of the academic curriculum. In this paper, we perform a short review of how the model of engineering education in Canada has evolved over the last two centuries, identify the current deficiencies in teaching design in engineering curricula, and review how Chairs in Design Engineering at various Canadian engineering schools have tackled this identified need. We then describe in detail how this problem is being addressed at the University of Waterloo through Engineering Design Days. This approach is presented as a design "lattice" around which other curriculum threads (math, natural sciences, engineering science, design etc.) can grow in an integrated way. Different Design Days examples from various engineering programs are described to illustrate the general structure. We conclude by assessing the program's impact and identifying opportunities for future development and assessment of the program's effectiveness.
\end{abstract}

Keywords: Design education, Design practice, Design learning, Experiential Learning, Professional Skills

Contact:

Hurst, Ada

University of Waterloo

Management Sciences

Canada

adahurst@uwaterloo.ca

Cite this article: Hurst, A., Rennick, C., Bedi, S. (2019) 'A "Lattice” Approach to Design Education: Bringing Real and Integrated Design Experience to the Classroom through Engineering Design Days', in Proceedings of the 22nd International Conference on Engineering Design (ICED19), Delft, The Netherlands, 5-8 August 2019. DOI:10.1017/ dsi.2019.46 


\section{INTRODUCTION}

Over the last two centuries, engineering education has been radically transformed from an apprenticeship-based model that was steeped in practice, to a highly academic classroom-based model that can struggle to find meaningful connections to the real world. This transformation has been driven by accelerating technological advances, which require engineering students to spend more and more time studying the fundamental concepts in math, and natural and engineering science. Without this ever-expanding foundation, they cannot engineer solutions to modern engineering problems.

Unfortunately, this overly "scholarly" educational model provides students limited connections to, and experience in, the actual practice of engineering and engineering design. Since 2001, engineering educators at many universities across Canada have sought to develop pedagogical innovations that can provide more meaningful and realistic engineering design education to students, within the context and constraints of modern professional higher-education.

These efforts have been particularly welcome at the University of Waterloo, which houses Canada's largest engineering school: 14 Engineering programs with almost 8000 undergraduates within the Faculty of Engineering. While all Waterloo engineering students participate in meaningful and frequent co-op experiences in industry (that add up to two years in total length), the practical experiences earned in industry have not been traditionally well-integrated with the academic curriculum. As such, new opportunities are sought to provide students with practical design experiences within the classroom. The purpose of this paper is to introduce a new paradigm - that of the "design lattice", and its embodiment in the form of Engineering Design Days. We begin by providing a brief history of the development of engineering education in Canada and by identifying some of its emerging challenges (Section 2). We then review how Canadian universities, including the University of Waterloo have sought to address these challenges (Section 3). In Section 4, we describe the design lattice paradigm and its implementation through the Engineering Design Days, and provide examples of how they manifest in different disciplines. We conclude by summarizing the overall impact of this initiative and identifying opportunities for future work.

\section{A BRIEF HISTORY OF CANADIAN ENGINEERING DESIGN EDUCATION}

Over the years, as the environment in which we live has changed, so has the profile of the engineer and engineering education. Three models of engineering education are discussed below, coinciding with the evolution of the marketplace from local to national to global.

\subsection{The apprenticeship model}

Until the 19th century, engineers met the needs of a local market economy; small-volume and highlycustomized products were made and sold locally. In this environment, the apprenticeship model of engineering education emerged (Britton, 2017, p. 196). One became an engineer through a "hands-on apprenticeship in a machine shop, at a drawing board, behind a transit, or on a construction site" (Seely, 2005, p. 115). A practicing engineer (master) took on a prospective practitioner (apprentice) and over time taught them skills pertinent to the engineering practice. The master focused on teaching not only design but also other necessary skills within the scope of the practice: economics, communication, interacting with customers, resilience, and problem solving. The quality of this training was therefore singularly dependent on the master. The apprentice learned in a holistic realworld setting, following and internalizing the steps taught by the master, with little to no theoretical knowledge. The abstraction of the design process was not part of this training, but its practical implementation was learned and experienced.

\subsection{The practising-engineer-as-a-teacher model}

It was not until the second half of the 19th century that some portion of engineering training came to the classroom. As local economies expanded, increased demand drove the increase in production volumes and with it, increased standardization. Batch production required larger numbers of apprentices with a broader set of skills. By 1860, Canada had well-organized two-year engineering programs in three universities (Harris, 1976). While this model provided less hands-on experience to trainees, it exposed them to a broader skill-set. The new training combined preparatory math, arts, and science courses with engineering courses taught by practicing engineers, who had achieved their 
expertise through experience (Harris, 1976). Still, at this time, engineering was considered a form of trade, lacking prestige. To some extent, the training provided was more suitable to developing technicians or technologists than professional engineers (Harris, 1976, p. 164). As economies grew even larger in scale, the need for engineers grew further. By the early 20th century, engineering programs grew in size and reputation, and by 1920, Canada had a number of well-established engineering programs and engineering faculties (Harris, 1976). At the same time, the seven provinces in Canada passed the first provincial acts designating engineering as a profession on the same level as law and medicine (DeVita, 2012). Still, the persisting educational model was such that while fundamental and preparatory courses were taught by professors, engineering courses were taught by practitioners, who alternated their time between university teaching and professional practice (Britton, 2017). Until the mid-20th century, engineering programs continued to have a very practical focus and were providing graduates with significant hands-on training (Tryggvason and Apelian, 2006); this was due in part to the scarcity of schools meant to train technologists as distinct from professional engineers (Harris, 1976).

\subsection{The professional-teacher model}

In the mid-20th century, with the beginning of the space age, the emphasis of engineering programs on fundamental training in math and science increased significantly (Tryggvason \& Apelian, 2006). The typical engineering curricula were such that students only took engineering courses after they had gained a solid basis in those subjects in their first 2-3 years of studies (Dym et al., 2005). By 1960, the demand for engineering training began to increase quickly, necessitating the creation of new schools of engineering, and four-year programs became the norm. Canadian universities also began offering advanced degrees in engineering, with seven faculties offering doctoral programs. A majority of undergraduate programs offered specializations in different engineering disciplines (Harris, 1976). This development removed engineering trainees further from the practical context, tying them almost exclusively to the academic context. The responsibility of teaching of engineering courses shifted from practicing engineers to academics who were highly specialized in their domains. The education model became more theory-based, and exposure to practical skills was reduced.

In parallel to these changes, the Canadian Engineering Accreditation Board (CEAB) was created in 1965 and began evaluating engineering programs offered by institutions to ensure that they met the educational standards needed for their graduates to register as professional engineers (Angeles et al., 2004). Recognizing that practicing engineers were no longer regularly teaching engineering courses, accreditation requirements were put in place such that engineering science and engineering design courses must be taught by licensed professional engineers.

In 1959, the University of Waterloo (Waterloo) started its five-year engineering program, in which students would study "everything from mathematics and economics to technical drawing and electronics", in addition to "semantics" (i.e., communication) (Redmond, 1998). The extended duration of the program also allowed students to alternate between four-month periods of in-classroom study and practical experience in industry (co-op). The mandatory co-op program was intended to place engineering students in engineering practice early and frequently, alongside engineering technologists and practicing engineers. This effort signified an early awareness that modern engineering education was not preparing engineers well for the needs of engineering practice outside of academia, and that engineering programs needed to include more practical experience.

\section{ENGINEERING EDUCATION TODAY}

Today the marketplace has evolved further into a truly global system. With increasing local and global competitiveness and a rapidly increasing rate of innovation, engineers in design teams are faced with new challenges and require a new set of design skills and competencies. As many of the products and services engineers design today are multi-disciplinary, they require the engineer to work in multidisciplinary teams, communicate effectively, be resilient in the face of failure, and be confident when stretched into new domains.

Certainly, at the end of the 20th century, engineering education in Canada was not well-suited to address this new reality. To help address this problem, in 2001, the National Science and Engineering Research Council (NSERC) launched the Chairs in Design Engineering program, with the mandate of advancing engineering design education in Canada. In 2004, the eleven original Chairs in Design Engineering (CDE) jointly sought to develop a definition of the engineering design competency. 
Through this process they identified some strategic issues that engineering programs needed to consider, including:

- Over-siloed engineering programs contrasted to multidisciplinary reality of engineering practice

- Limited and book-end approach to teaching design

- Lack of hands-on design experience, specifically in the use of tools and processes relevant to engineering practice

- $\quad$ Lack of exposure to and training in teamwork and communication (Angeles et al., 2004)

The different CDE programs across the country responded to this need in different ways depending on the specific needs and contexts of their institutions. Some typical initiatives included the expansion of design and prototyping facilities (e.g., University of Ottawa); enhancement of engineering design curricula through development of design "continua" or "spines" with new engineering design courses at all program levels (e.g., Dalhousie University); support for multidisciplinary engineering training, including through (client-based) multidisciplinary capstone design projects (e.g., University of Toronto), integration of engineering design with entrepreneurship training (e.g., University of Ottawa), increased student exposure to practicing engineers (e.g., University of New Brunswick); development of professional skills, for example through a "professional spine" (e.g., University of Calgary), increased training in sustainable design and Indigenous perspectives (e.g., University of Manitoba), and expanding engineering design training at the graduate level (e.g., University of Calgary). (Government of Canada, 2016)

The first Chair in Design Engineering at the University of Waterloo was established in 2005 in the form of Waterloo Cases in Design Engineering (WCDE). While all students at the University of Waterloo were taking advantage of the co-op program to gain practical experience in industry, that practical experience remained firmly outside the classroom and was not systematically integrated with the academic curriculum. Taking advantage of the distinct opportunities that the co-op program offered, the WCDE took the approach of exposing students to the complexities of real-life engineering practice through the creation of case studies that were co-written by students based on their specific co-op experiences (Lambert, Newton, \& Effa, 2016). In addition to creating a significant database of engineering design cases, in its ten years WCDE also supported instructors in bringing these cases to the classroom through development of teaching resources, including presentations and other multimedia materials and case-teaching workshops.

\section{DESIGN LATTICE: A NEW PARADIGM FOR ENGINEERING DESIGN EDUCATION}

While the case studies developed by WCDE converted some of the real-world experiences into practical learning conduits that could be brought to a large class, they were not able to address larger structural problems in the curricula, including highly siloed courses, lack of hands-on exposure, and lack of training in teamwork and communication skills. Engineering programs at Waterloo remained heavily siloed, the problem compounded by a cohort system that assigns students to their disciplinespecific classes immediately upon first-year entry. Moreover, design teaching was confined to the book-ends, with most programs offering two-term capstone design sequences in fourth year and introductory design courses in first year. Relatively few programs had any dedicated design courses at the intermediate levels, though small embedded design experiences in course projects were not uncommon. Unfortunately, course-based projects are limited in size and scope and tend to only use content and skills taught in that specific course. Thus, design experiences were limited and fragmented between courses and program threads.

Yet, real-world design practice is multidisciplinary by nature. This mismatch is one of the main reasons why past attempts to bring in design experiences into singular courses have suffered. Any solution to this problem must live outside of the courses, yet be integrated with the curriculum. Our proposed paradigm addresses these deficiencies by adding a design experience, which, while situated outside regular courses, has meaningful links to the academic content taught in those courses. We liken this paradigm to a "design lattice", separate from the traditional curriculum, upon which the different knowledge domains of a department can be supported, and where students can build their core engineering and engineering design skills - both technical and professional.

An embodiment of this vision - given the name of Engineering Design Days (Design Days) - is an activity that occurs partway through an academic term where students pause their academic studies, 
and work in teams to solve an authentic design problem. The problem shows students the context of the material they are learning in class, and integrates the knowledge they are learning from their various courses. As the activity takes place outside of the main curriculum thread, it is not limited by the bounds of a specific course, and so is positioned to support all knowledge domains equally. As the activity is ill-structured and authentic in nature, it also provides support for students' professional skills development. This model is similar to the integration activities described by Maciejewski et al. (2018), but extended to all programs, and without the full curriculum integration that Colorado State University is implementing.

\section{ENGINEERING DESIGN DAYS}

\subsection{History}

In 2014, the Dean of Engineering launched the Engineering Ideas Clinic (EIC) to implement the design lattice vision - and with it Design Days - across the faculty. At the onset, the EIC was comprised of a group of instructors and staff in the Mechatronics Engineering program who had been successfully implementing integrative, hands-on projects for several years (see Hulls et al. (2014), Hulls et al. (2015) and Bedi et al. (2017) for more details on these early initiatives). After two years of successful growth, in 2016 Waterloo was awarded a new Chair in Design Engineering: the NSERC Chair in Immersive Design Engineering Activities (IDEAs) to continue spreading the concept to all years of all programs. This initiative was strongly influenced by the pioneering project-based design approach used by Harvey Mudd College (Dym et al., 2012), with the significant added challenge of scaling that approach from a school of approximately 200 students to the nearly 8000 in 14 engineering programs at Waterloo.

\subsection{Engineering design days}

Hackathons have been shown to promote engagement, innovation, teamwork, and problem-solving in engineers both while they are at university (Byrne, O'Sullivan and Sullivan, 2017; Tandon et al., 2017), as well as once in industry (Komssi et al., 2015); however, examples of hackathons used as classroombased instructional activities are very uncommon (see Calco and Veek (2015) as one exception). Integrative curricula on the other hand - listed as the third anticipated trend in engineering education (Graham, 2018) - are no longer uncommon in engineering programs worldwide. They are widely recognized as a means of promoting inter-disciplinarity, knowledge retention, and collaboration, and are well-positioned to demonstrate the relevance of different subjects to the practice of engineering (AlHolou et al., 1999). Worldwide, Olin College (Somerville et al., 2005) and the Singapore University of Technology and Design (Graham, 2018), are prominent examples to use integrated curricula throughout their engineering programs. The only such example in Canada is the Mech 2 program at the University of British Columbia (University of British Columbia, 2019). Despite their promise and potential, hackathons and integrative curricula come with their own set of challenges and limitations. For example, hackathons have been found to ostracize under-represented populations in STEM fields (Johnson, 2014), while integrated curricula have been typically only implemented in units with small student populations (Olin College has only a total of 350 undergraduate students across all programs, for example).

Design Days at the University of Waterloo were conceived as integrative, hackathon-like activities that act as anchors for various courses and take place during regularly scheduled class hours. This new activity format, much like a lattice, provides support to the various courses that term. In addition, the format would seek to capture the engagement and creativity present at hackathons with the powerful student learning present in integrating course concepts. Design Days would provide just enough structure to ensure all students had a positive experience, without becoming overly prescriptive. Most importantly, the concept would have to work for class sizes of up to 240 students, while being flexible enough to be implemented in a wide range of engineering programs. Informed by the success of a similar classroom activity in the Management Engineering program (McKay et al., 2016), the first Design Days activity in Mechatronics Engineering presented students with assigned problems that were designed to integrate topics taught in chemistry, algebra, calculus, design, and programming in the first semester of the program (Li et al., 2017). This first Design Days activity demonstrated the value of the concept, but was lacking in hands-on design, and was overly prescriptive. While some of the early pioneers implemented Design Days in unique ways that better fit their specific needs and departmental culture (Ivkovic et al., 2017), a common structure began to develop as the concept was refined. 
Presently, Design Days activities are typically completed by teams of 4-5 students, and take place over two days with 12-16 hours of student contact time. During the first half day of the activity (typically the morning of the first day) students work to solve some warm-up problems (Stage 1). These are typically simpler problems that are designed to require students to connect the material from multiple courses in which they are enrolled. These warm-up problems serve two main purposes: to show how the material in multiple courses connect to engineering problems, and to reactivate the domain knowledge the students will need to solve the discipline-specific design problem they are later assigned in Stage 2. Once the detailed design has been completed in Stage 2, students receive feedback on their design from the course teaching team. During Stage 3 of the activity (which is typically the morning of day two), students begin building their proposed solution. Finally, in Stage 4, students perform design verification, typically through testing and demonstration. Table 1 summarizes this schedule, providing specific details from Design Days activities in three different disciplines. The rows of the table outline the program, level, design challenge, and content in each stage of the activity for each of the three different implementations.

Table 1. Summary of Design Days activities in Mechatronics, Mechanical and Civil Engineering

\begin{tabular}{|c|c|c|c|}
\hline Program & $\begin{array}{l}\text { Mechatronics Engineering } \\
\text { (Rennick et al., 2018) }\end{array}$ & $\begin{array}{l}\text { Mechanical Engineering } \\
\text { (Rennick et al., 2018) }\end{array}$ & $\begin{array}{l}\text { Civil Engineering } \\
\text { (Philips et al., 2018) }\end{array}$ \\
\hline Level & Year 1, Semester 1 & Year 1, Semester 2 & Year 2, Semester 1 \\
\hline Challenge & $\begin{array}{l}\text { Design tele-operated "pick } \\
\text { and place" robotic arm } \\
\text { that lifts 3D printed } \\
\text { components from the } \\
\text { ground and place them in } \\
\text { holders on a vertical wall. }\end{array}$ & $\begin{array}{l}\text { Design water-powered } \\
\text { mechanical clock that } \\
\text { counts } 3 \text { seconds with } \\
\text { high repeatability. Modify } \\
\text { clock to accurately time } 3 \\
\text { minutes. }\end{array}$ & $\begin{array}{l}\text { Design highway } \\
\text { bridge over a river. } \\
\text { Make cost trade-offs } \\
\text { between the highway } \\
\text { design and the bridge } \\
\text { location. }\end{array}$ \\
\hline $\begin{array}{l}\text { Stage 1: } \\
\text { Warm-up }\end{array}$ & $\begin{array}{l}\text { Model forward and } \\
\text { inverse kinematics of } \\
\text { simplified system (limited } \\
\text { to } 2 \text { degrees of freedom) } \\
\text { using knowledge from } \\
\text { calculus and algebra } \\
\text { courses. }\end{array}$ & $\begin{array}{l}\text { Analyse available energy } \\
\text { in water source, explore } \\
\text { simple electric circuits } \\
\text { which include a tilt } \\
\text { sensor. Apply knowledge } \\
\text { from circuits and physics. }\end{array}$ & $\begin{array}{l}\text { Plan highway route, } \\
\text { select river crossing } \\
\text { location on a } \\
\text { topographic map } \\
\text { using knowledge } \\
\text { from transportation } \\
\text { and materials courses }\end{array}$ \\
\hline $\begin{array}{l}\text { Stage 2: } \\
\text { Design }\end{array}$ & $\begin{array}{l}\text { Explore available } \\
\text { equipment and complete a } \\
\text { hand sketch of detailed } \\
\text { system design using skills } \\
\text { from engineering graphics } \\
\text { course }\end{array}$ & $\begin{array}{l}\text { Perform conceptual } \\
\text { design and determine } \\
\text { system specifications } \\
\text { using knowledge from } \\
\text { mechanical engineering } \\
\text { design course }\end{array}$ & $\begin{array}{l}\text { Design scale model } \\
\text { of bridge required to } \\
\text { cross river, complete } \\
\text { structural analysis } \\
\text { using real material } \\
\text { data and knowledge } \\
\text { from mechanics and } \\
\text { materials courses }\end{array}$ \\
\hline $\begin{array}{l}\text { Stage 3: } \\
\text { Build }\end{array}$ & $\begin{array}{l}\text { Construct solution using } \\
\text { small pneumatic cylinders, } \\
\text { Tetrix Prime kits, and } \\
\text { common crafting materials }\end{array}$ & $\begin{array}{l}\text { Construct solution using } \\
\text { custom laser cut parts, } \\
\text { Tetrix Prime kits, and } \\
\text { common crafting } \\
\text { materials }\end{array}$ & $\begin{array}{l}\text { Construct bridge as } \\
\text { designed out of rigid } \\
\text { foam insulation }\end{array}$ \\
\hline $\begin{array}{l}\text { Stage 4: } \\
\text { Verification }\end{array}$ & $\begin{array}{l}\text { Demonstrate working } \\
\text { design to course teaching } \\
\text { team }\end{array}$ & $\begin{array}{l}\text { Demonstrate working } \\
\text { design to course teaching } \\
\text { team }\end{array}$ & $\begin{array}{l}\text { Perform destructive } \\
\text { testing and verify } \\
\text { design parameters }\end{array}$ \\
\hline
\end{tabular}


The design challenges that students solve during Design Days are discipline-specific, ill-structured, and open-ended. Students are given as little information as possible during the event to force them to be creative, to investigate the resources available, and to pool their collective experience. The challenges are designed so that $75 \%$ or more of the class are expected to finish designing their solution within the allotted time, and typically have space for the exceptional students to push their designs beyond the minimum requirements. In addition to those described in Table 1, other design challenges have included the design and construction of full-scale furniture made of plaster and honeycomb cardboard in Architectural Engineering, earthen dams built with real materials including small hydroelectric generators in Environmental Engineering, a cross-section of a landfill in Geological Engineering, and a video game focussing on collaborative software development in Software Engineering (see Rennick et al. (2017), Phillips et al. (2018) and Rennick and McKay (2018) for more details on these and other activities). Figure 1 shows some of the projects students have completed in the Design Days activities in Architectural, Environmental, and Geological Engineering.

\section{IMPACT, CHALLENGES, AND FUTURE WORK}

Design Days have been very successful in first and second years of various engineering programs at Waterloo. The EIC continues to be engaged in a number of initiatives to improve and extend the delivery and assessment of Design Days to upper years, with the vision of extending the design lattice across all years in the near future. Development of new activities has been proceeding steadily since the first activities were launched in fall of 2016. By the end of the winter 2019 semester, student cohorts in 12 out of 14 programs will have participated in a Design Days activity in first year, and three will have had one in second year. Most importantly, the success of this model at Waterloo has shown that it can scale to both large student cohorts (typical class sizes are 100-120 students), and to a diversity of engineering disciplines.

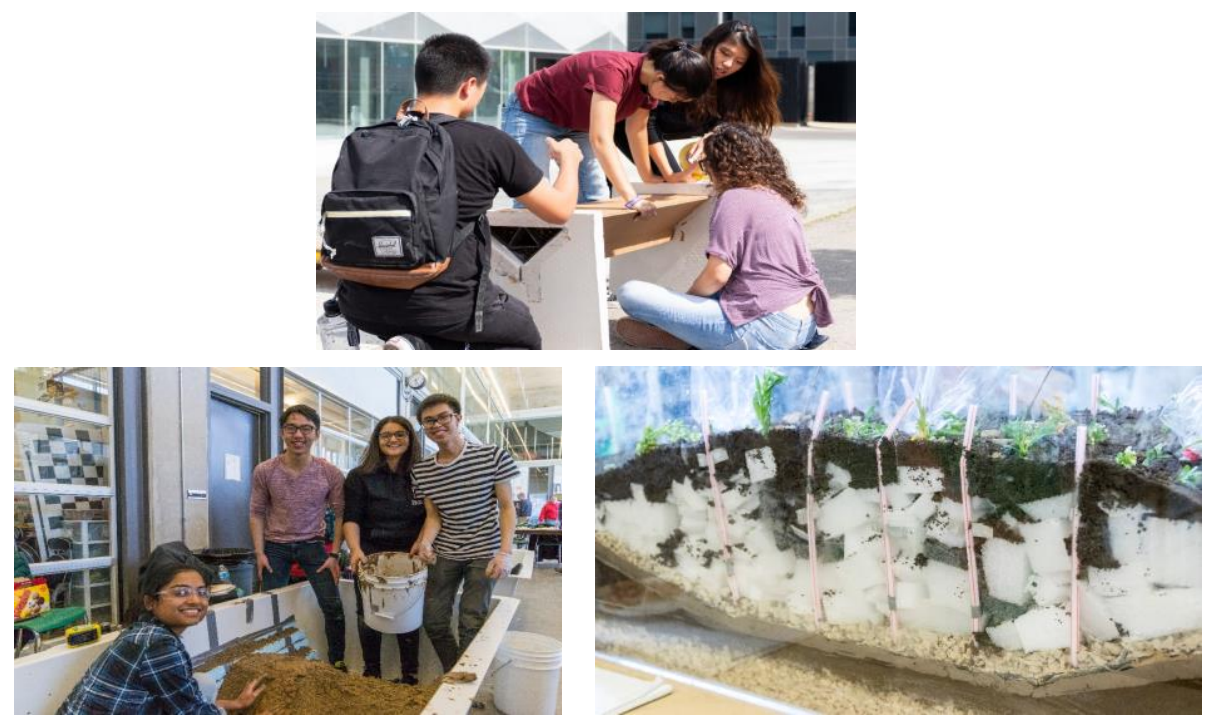

Figure 1. Students working on Design Days (top, Architectural Engineering students constructing a bench; bottom, Environmental Engineering students constructing an earthen dam and an example of a landfill from a Geological Engineering activity)

\section{1 (Multi-disciplinary) teamwork}

In addition to design skills, Design Days also help students develop professional skills, including teamwork, reflection, and communication. Students develop teamwork skills explicitly through EICdeveloped teamwork training workshops (see Hurst et al. (2016), Al-Hammoud et al. (2017), Hurst et al. (2018) and Jobidon et al. (2018) for details on these); and also implicitly, by being required to work on demanding projects in teams that require them to rely on their classmates to be successful. Most of the activities are followed by guided reflection that prompt students to take notice and make sense of their design experience. These reflections also provide an opportunity to practice communications skills on a meaningful personal experience. 
While Design Days have successfully integrated concepts and skills from different courses within a program, the siloed and cohort-based nature of our engineering programs have so far constrained most of these activities to be discipline specific. There have been, however, some Design Days activities that have joined students from "adjacent" disciplines, such as electrical and computer, and biomedical and systems design. These have set a positive precedent for the EIC, which is looking to improve future offerings of Design Days in ways that give students more opportunities to work in multidisciplinary teams that better mimic engineering practice.

\subsection{Measuring effectiveness}

The effectiveness of Design Days has so far been assessed for each activity individually, typically by instructors measuring learning outcomes as they pertain to their own course/program. This assessment is most commonly conducted as pre-/post- surveys, as well as through interviews, focus groups, and/or open text survey questions. Student surveys have shown that a majority enjoy these activities and want them to continue in future years. For example, over half of the surveyed Mechatronics Engineering students believe that Design Days are very or extremely important for future students. In addition, an overwhelming majority think Design Days are a good context in which to practice teamwork and other professional skills. Across all surveys, about two thirds of students express that Design Days linked content between courses. (Rennick et al., 2018; Philips et al., 2017; Ivkovic et al., 2017)

Design Days provide an opportunity for students to solve difficult, open-ended and ill-structured problems. While existing assessment instruments have proven Design Days are capable of achieving course-level learning outcomes and of improving skills like teamwork, due in part to their decentralized nature, they have provided little understanding of if and how the activities are improving student design skills. Yet, given their design and reach, Design Days provide an opportune environment to systematically observe students in authentic problem-solving situations, measure student outcomes, and improve how we design future activities to target these skills. As such, we have recently sought and secured funding to develop a comprehensive framework for systematically measuring the effectiveness of Design Days activities at improving student design skills. Using an adapted framework based on Jonassen (2000) we will assess the combined effect of the characteristics of the design problems as well as the individual students on student design outcomes.

A final area of interest is improving student skills in the need identification stage of the design process. While Design Days provide students with the practical experience of designing solutions to real(istic) problems early and frequently, the problems that are presented to students are already fully or partially formulated for them. In most engineering programs at Waterloo, students may not be given a chance to identify their own problem to solve until the capstone design project. We believe that this deficiency significantly impacts the quality of the completed capstone projects, and limits their chances for future commercialization. Therefore, future work will concern the development of Design Days with a focus on need identification and problem formulation.

\section{CONCLUSION}

We began this paper by outlining the historical context that transformed the teaching of engineering design from one that was steeped in practice and under the apprenticeship of a practicing engineer to one that moved almost completely to the classroom under the instruction of academics with little practical engineering experience. While we have focused on the Canadian context, this progression was far from unique to Canada. This profound shift created significant gaps in student opportunities to partake in and learn from authentic design experiences. To address this, initiatives in the 21st century in many Canadian universities, including at Waterloo, were varied in philosophy and scope. In the end, what has emerged at Waterloo is the recognition that for design teaching to be effective, it must be taught in an authentic and hands-on context, and outside the confines of a singular course. Design Days, are being used to build a design lattice that exposes students to design experiences early, frequently, and in a way that integrates knowledge from different courses. We believe this teaching innovation already has and will continue to impact engineering design teaching in a meaningful way. Future systematic assessment of the activities will help drive continuous improvement. 


\section{REFERENCES}

Al-Hammoud, R., Hurst, A., Prier, A., Mostafapour, M., Rennick, C., Hulls, C., Jobidon, E., Li, E., Grove, J. and Bedi, S. (2017), “Teamwork for Engineering Students: Improving Skills Through Experiential Teaching Modules", Proceedings of the Canadian Engineering Education Association (CEEA) Conference, Toronto, June 4-7, 2017. https://doi.org/10.24908/pceea.v0i0.9414

Angeles, J., Britton, R., Chang, L., Charron, F., Gregson, P., Gu, P., Lawrence, P., Stiver, W., Strong, D., Stuart, $\mathrm{P}$ and Thompson, B. (2004), "The engineering design competency", Proceedings of the Canadian Design Engineering Network Conference, Montreal, July 29-30, 2004. https://doi.org/10.24908/pceea.v0i0.3991

Bedi, S., Hulls, C., Rennick, C., Robinson, M. and Melek, W. (2017), "Design of an Introductory Engineering Design and Communication Course Which Integrates First Semester Courses", Proceedings of the Canadian Engineering Education Association (CEEA), Toronto, June 4-7, 2017. https://doi.org/10.24908/pceea.v0i0.9477

Britton, R. (2017), On Design, Friesen Press, Victoria, BC.

Byrne, J.R., O’Sullivan, K. and Sullivan, K. (2017), “An IoT and Wearable Technology Hackathon for Promoting Careers in Computing Science", IEEE Transactions on Education, Vol. 60, No. 1, pp. 50-58. https://doi.org/10.1109/TE.2016.2626252

Calco, M. and Veeck, A. (2015), "The Markathon: Adapting the Hackathon Model for an Introductory Marketing Class Project”, Marketing Educational Review, Vol. 25, No. 1, pp. 33-38. https://doi.org/10.1080/10528008.2015.999600

DeVita, P. (2012), “A short history of PEO’s beginnings”, Engineering Dimensions, January/February 2012, pp. $26-28$.

Dym, C. L., Agogino, A.M., Eris, O., Frey, D.D. and Leifer, L.J. (2005), "Engineering Design Thinking, Teaching, and Learning”, Journal of Engineering Education, Vol. 94, No. 1, pp. 103-120. https://doi.org/10.1002/j.2168-9830.2005.tb00832.x

Dym, C.L., Gilkeson, M.M. and Phillips, J.R. (2012), "Engineering Design at Harvey Mudd College: Innovation Institutionalized, Lessons Learned”, Journal of Mechanical Design, Vol. 134, No. 8, p. 080202. https://doi.org/10.1115/1.4006890

National Academy of Engineering. (2005), Educating the Engineer of 2020: Adapting Engineering Education to the New Century, The National Academies Press, Washington, DC. https://doi.org/10.17226/11338

Frank, B., Strong, D. and Sellens, R. (2011), "The Professional Spine: Creation of a Four-year Engineering Design and Practice Sequence", Proceedings of the 2nd Annual CEEA Conference, St. John's, June 6-8, 2011. https://doi.org/10.24908/pceea.v0i0.3586

Frise, P.R., Rohrauer, G.L., Minaker, B.P. and Altenhof, W.J. (2003), "Identifying the Design Engineering Body of Knowledge", DS 31: Proceedings of ICED 03, the 14th International Conference on Engineering Design, Stockholm, August 19-21, 2003.

Government of Canada. (2016), "NSERC - Chairholder Detail Search”, available at: http://www.nserccrsng.gc.ca/Chairholders-TitulairesDeChaire/Index_eng.asp (accessed 20 November 2018).

Graham, R. (2018), The Global State of the Art in Engineering Education, Massachusetts Institute of Technology, Cambridge, MA.

Harris, R.S. (1976), A History of Higher Education in Canada 1663-1960, University of Toronto Press.

Hulls, C., Rennick, C., Robinson, M., Melek, W. and Bedi, S. (2014), "Integrative Activities for First Year Engineering Students-Fuel Cell Cars as a Linking Project Between Chemistry, Mechatronics Concepts and Programing", Proceedings of the Canadian Engineering Education Association (CEEA), Canmore, June 8-11, 2014. https://doi.org/10.24908/pceea.v0i0.5957

Hulls, C., Rennick, C., Bedi, S., Robinson, M. and Melek, W. (2015), “The Use of an Open-Ended Project to Improve the Student Experience in First Year Programming”, Proceedings of the Canadian Engineering Education Association (CEEA), Hamilton, May 31-June 3, 2015. https://doi.org/10.24908/pceea.v0i0.5737

Hurst, A., Barichello, M., Jobidon, E. and Al-Hammoud, R. (2018), “A Team Health Self-Assessment Tool and Workshop for Engineering Student Teams", Proceedings of the Canadian Engineering Education Association (CEEA) Conference, Vancouver, June 3-6, 2018. https://doi.org/10.24908/pceea.v0i0.12969

Hurst, A., Jobidon, E., Prier, A., Khaniyev, T., Rennick, C., Al-Hammoud, R., Hulls, C., Grove, J., Mohamed, S., Johnson, S.J. and Bedi, S. (2016), "Towards a Multidisciplinary Teamwork Training Series for Undergraduate Engineering Students: Development and Assessment of Two First-year Workshops", Proceedings of ASEE's 123rd Annual Conference \& Exposition, New Orleans, June 26-29, 2016. https://doi.org/10.18260/p.27065

Ivkovic, I., Willett, T.L., Borland, M.J. and Gorbet, M. (2017), "Design Days Boot Camp: Enhancing Student Motivation to Start Thinking in Engineering Design Terms in First Year", Proceedings of the Canadian Engineering Education Association (CEEA), Toronto, June 4-7, 2017. https://doi.org/10.24908/pceea.v0i0.9759

Jobidon, E., Barichello, M., Al-Hammoud, R., Mostafapour, M., Rennick, C., Hurst, A. and Grove, J. (2018), "Building Engineering Professional and Teamwork Skills: A Workshop on Giving and Receiving 
Feedback”, Proceedings of the 2018 ASEE Annual Conference \& Exposition, Salt Lake City, June 24-27, 2018. https://peer.asee.org/30163

Johnson, P. (2014), "How hackathons can become more female-friendly", PC World [online], available at: https://www.pcworld.com/article/2098246/how-hackathons-can-become-more-female-friendly.html

Jonassen, D.H. (2000), "Toward a Design Theory of Problem Solving”, Educational Technology Research and Development, Vol. 48, No. 4, pp. 63-85. https://doi.org/10.1007/BF02300500

Komssi, M., Pichlis, D., Raatikainen, M., Kindstrom, K. and Jarvinen, J. (2015), "What are Hackathons for?" IEEE Software, Vol. 32, No. 5, pp. 60-67. https://doi.org/10.1109/MS.2014.78

Lambert, S., Newton, C. and Effa, D. (2016), "Ten Years of Enhancing Engineering Education with Case Studies: Insights, Lessons and Results from a Design Chair", Proceedings of the Canadian Engineering Education Association (CEEA) Conference, Halifax, June 19-22, 2016. https://doi.org/10.24908/pceea.v0i0.6508

Li, E., Rennick, C., Hulls, C., Robinson, M., Cooper-Stachowsky, M., Boghaert, E., Melek, W. and Bedi, S. (2017), "Tron Days: Horizontal Integration and Authentic Learning", Proceedings of the Canadian Engineering Education Association (CEEA), Toronto, June 4-7, 2017. https://doi.org/10.24908/pceea.v0i0.7347

Maciejewski, D.A.A., Chen, T., Byrne, Z.S., Reese, M.D., Notaros, B.M., Pezeshki, A., Roy, D.S. et al. (2018), "Throwing Away the Course-centric Teaching Model to Enable Change", Proceedings of the 2018 ASEE Annual Conference \& Exposition, Salt Lake City, June 24-27, 2018. https://peer.asee.org/31142

McKay, K.N., Mohamed, S. and Stacey, L. (2016), "Concepts Only Please! Innovating a First Year Engineering Course", Proceedings of the Canadian Engineering Education Association (CEEA) Conference, Halifax, June 19-22, 2016. https://doi.org/10.24908/pceea.v0i0.6515

Phillips, S.J. (2018), "Enhancing Student Learning by Providing a Failure Risk-free Environment and Experiential Learning Opportunities", Proceedings of the 2018 ASEE Annual Conference \& Exposition, Salt Lake City, June 24-27, 2018. https://peer.asee.org/30429

Redmond, C. (1998), "1865-1956: Roots and tributaries", Water Under the Bridge: An Unofficial History of the University of Waterloo, University of Waterloo, Waterloo, ON, available at: https://uwaterloo.ca/waterunder-the-bridge/1865-1956 (accessed 19 November 2018).

Rennick, C., Hulls, C., Wright, D., Milne, A.J.B., Li, E. and Bedi, S. (2018), "Engineering Design Days: Engaging Students with Authentic Problem-Solving in an Academic Hackathon", Proceedings of the 2018 ASEE Annual Conference \& Exposition, Salt Lake City, June 24-27, 2018. https://peer.asee.org/30407

Rennick, C. and McKay, K.N. (2018), "Componential Theories of Creativity: A Case Study of Teaching Creative Problem Solving", Proceedings of the Canadian Engineering Education Association (CEEA) Conference, Vancouver, June 3-6, 2018. https://doi.org/10.24908/pceea.v0i0.12991

Seely, B.E. (2005), "Patterns in the History of Engineering Education Reform: A Brief Essay", in National Academy of Engineering, Educating the Engineer of 2020: Adapting Engineering Education to the New Century, The National Academy Press, Washington, DC, pp. 114-130. https://doi.org/10.17226/11338

Somerville, M., Anderson, D., Berbeco, H., Bourne, J.R., Crisman, J., Dabby, D., Donis-Keller, H., Holt, S.S., Kerns, S., Kerns et al. "The Olin Curriculum: Thinking Toward the Future", IEEE Transactions on Education, Vol. 48, No. 1, pp. 198-205. https://doi.org/10.1109/TE.2004.842905

Tandon, J., Akhavian, R., Gumina, M. and Pakpour, N. (2017), "CSU East Bay Hack Day: A University Hackathon to Combat Malaria and Zika with Drones", Proceedings of the 2017 IEEE Global Engineering Education Conference (EDUCON), Athens, Greece, April 25-28, 2017. https://doi.org/10.1109/EDUCON.2017.7942968

Tryggvason, G. and Apelian, D. (2006), "Re-engineering engineering education for the challenges of the 21st century", JOM: Journal of the Minerals, Metals \& Materials Society, Vol. 58, No. 10, pp. 14-17. https://doi.org/10.1007/s11837-006-0194-6

The University of British Columbia. (2019), "Mech 2", available at: http://mech.ubc.ca/undergraduate/mech-2/ (accessed 17 March 2019).

\section{ACKNOWLEDGMENTS}

The work described in this paper has been conducted over many years by dozens of people, the efforts of which the authors would like to acknowledge. In particular, the authors would like to acknowledge the efforts of Ken McKay, Carol Hulls, Mary Robinson, Eugene Li, Igor Ivkovic, Derek Wright, Andrew Milne, Pete Teertstra, Jenn Coggan, Derek Rayside, and Rania Al-Hammoud in developing the individual Design Days activities. Lastly, the authors would like to acknowledge the Dean of Engineering, Dr. Pearl Sullivan. Without her vision and support of the Engineering Ideas Clinic over many years, this would not have been possible. 